\title{
Variations In Language: Teaching Within The Confines Of Black English In Rural Georgia
}

Amelia Simmons, East Georgia State College, USA

\begin{abstract}
It is the purpose of this paper to describe how the identification of linguistic differences in Black English helped eradicate the language barrier in a rural Georgia classroom and enhanced the communication between the teacher and the students.
\end{abstract}

Keywords: Black English Dialect; Teaching African-American Students; Linguistic Variations; Language Barrier; Standard English

\section{INTRODUCTION}

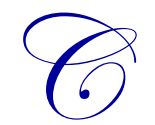

obwebs sometimes appear overnight, even in the best-kept quarters. When I taught writing and literature at the secondary level over twelve years ago, I thought that I could tackle any obstacle that blocked my way. However, the intricate variations within the "cobweb" of language entered within the walls of my classroom. Most Americans know that the Southern United States region has a distinct dialect of its own, and this "Southern gentile speech" comes with certain customs and traditions relevant to the culture. It is not the only language in the South. Black English is another dialect dominant in the area, and I was not only faced with a culture unknown to be but also with an incomprehensible dialect. This paper discusses the language barriers I encountered teaching African-American students and by acknowledging the linguistic differences in dialect, I was able to eradicate this miscommunication.

In a society like the United States, language patterns vary. A variety of dialects, which are "distinguished from other patterns based on pronunciation, grammar, lexicon, and semantics," are spoken and written daily, ranging from region, occupation, sex, education, age, and social context (Millward, 1996, p. 348). According to Teaching the English Language, Bushman (1988) states that "students and teachers should be informed about dialects whether they are regional, social, or nonstandard. Knowing about Black English and various regional dialects will give both teachers and students a better understanding and appreciation of the English language" (p. 109). Not being familiar with my African American students' dialect was my handicap as a high school teacher based upon my private school education and my complete ignorance of the language and culture. Black English is "an ethnic and socioeconomic variety of the language, defined by the social position and education of its speakers and is the nonstandard English used by some blacks in the United States" (Millward, 1996, p. 360). It embodies speakers from "a scattered family that includes African pidgins, Caribbean Creole, the English of the southern states of America, and the Black English of post-colonial British Isles" (McCrum, Cran, \& MacNeil, 1992, p. 184).

Linguistic research has found five systematic differences between the black nonstandard dialect and Standard English: optional copula deletion, negative concord, invariant "be," dummy "it," and negative inversion (DeStefano, 1973). It is the purpose of this paper to describe how the identification of such linguistic differences helped eradicate the language barrier in the classroom and enhance the communication between the teacher and the students. 


\section{COPULA DELETION}

I taught in a large county in East Central Georgia that had consolidated the high school. A majority of my students were African-American from impoverished backgrounds. It was not surprising to discover that many students were either members of various gangs, single-parents, or repeating the same grade. My expectations of instructing a crowd of rural students who loved country music was quickly destroyed by the realization that the students sitting my classroom were from the urbanized ghetto who loved sex, drugs, and rap. They did not speak with a country accent like myself and regarded my speech to be foreign. Raised in a small town in Georgia, I possess the typical Georgian accent common to those in the area. However, my days of instruction did not consist of "ya' ll" and "ain't gonna." I found my world involving the following example from Student A: "'Miz, you missin' everthang. We got crunk dis weeken, an den I fightin' cuz dez one gurl say she tired of my friend's mouf an I toll her she betta quit talkin' bout my frien' cause she don't take no mess."'1 These words resonated on a daily basis, becoming a language of its own, distinctive to the culture. At first, I had no idea what "crunk" meant or really the rest of the long run-on sentence. Sadly, the student had to repeat herself to me over three times because I could not understand her discourse. The most obvious problem was the copula deletion that I soon discovered as the omission of the "be" verb. It became more apparent when I held class discussions that resulted in Student B saying that "Poe my man an he referrin' to death,"” or "'Mis, she eatin' a urge.",2 In her essay "It Bees Dat Way Sometime," Smitherman (1998) writes that "the Black English speaker omits the be verb . . and applying the non-be rule, you get an absence of be before the nouns, adjectives, adverbs, prepositional phrases, and auxiliary constructions" ( $p$. 332). In most cases, the verb is deleted in African American English (AAE) sentences if "in Standard English the verb can be contracted" (Fromkin \& Rodman, 1998, p. 415).

\section{THE NEGATIVE CONCORD}

Another variation was the negative concord or use of the double negative by my African American students. Despite its common use among many individuals and cultures today, "triple and quadruple negatives are the sole province of Africanized English" (Smitherman, 1998, p. 338). I was showered with refusals to complete work by Student C: “'I ain't doin' nuthin' yo say cuz I don't got no sheets."'3 In addition, questions about assignments had to be repeated to me more than twice because I could not comprehend the student due to "negative constructions that occur in AAE" (Fromkin \& Rodman, 1998, p. 414). When I heard Student C ask "What yo say we ain't gotta no do,",4 the compilation of double negatives and dialect both contributes to my confusion. Although, I must admit that Southerners tend to use double negatives as well since "double negatives are a part of many current white dialects in the English-speaking world, and were the standard in an earlier stage of English" (p. 414). Part of my own youth consisted of hearing comments such as “"I ain't gonna do nothing today" along with "'I've done did it."”

\section{THE INVARIANT "BE"}

The invariant "be" is a third variation in the black nonstandard dialect. Without the "be," the speaker expresses a momentary condition, and with the "be," the speaker expresses a recurrent action. My students used this variation all of the time in class, and I found myself correctly them constantly. When I would call roll, instead of saying, "I'm here," some of the students would reply, "'I be here." Other times, when questioned about the location of certain individuals, the students would reply, "'He be in office,"” or "'He be home."”

In his essay "The Study of Nonstandard English," William Labov (1998) writes "nonstandard Negro English has one distinction which standard English does not have: there is an invariant form be in 'He always be foolin' around' which marks habitual, general conditions" (p. 315). He states further that "speakers of Standard English must be more cautious in claiming to understand the meaning of 'I be here" as opposed to 'I am here' in

\footnotetext{
${ }^{1}$ Student A means, "Miss, you are missing everything. We had fun this weekend, and then I got into a fight because of one girl who said that she was tired of my friend's mouth. I told her that she should stop talking about my friend because she will not tolerate it."

${ }^{2}$ Student B means that "Edgar Allen Poe is his favorite author and that he is referencing death in the selected work." The other statement simply means that the girl is eating a piece of fruit known as an orange.

${ }^{3}$ This statement translates into "I am not completing the assignment because I do not have the worksheets."

${ }^{4}$ This simply means that the student is asking what they do not have to complete on particular assignment.
} 
nonstandard Black English because of the existence of the other form" (p. 315). In order to decipher the meaning of my students' speech, I had to depend heavily on decoding through the use of contextual clues.

\section{NEGATIVE INVERSION, REDUNDANCY, AND LACK OF POSSESSIVES}

Not only did my students "be using be," but also they added the "ed" suffix to strong verbs and misused the word "done." I noticed that several students would speak and would write that "they goed to town, and they ated strips at the Chicken Hut." Many students misinterpreted the "use of 'done' as an auxiliary to indicate that the action took place in the recent past" (Millard, 1996, p. 363). "That boy done finished"” means that the male student just finished his work, and "She done stole the paper"" refers to a female student taking someone else's work recently. Reasons for these uses of done are explained by Smitherman (1998) who writes that "what is important to keep in mind is the distinction between done used by itself and done used in combination with other verbs" (p. 334). The use of done within Black English statements can vary; sentences using only done "means the White English did," but using done with another verb is equivalent to the "White English form of have" (p. 334).

Other characteristics of the Black English dialect include lack of possessives, redundant subjects, omission of "have," and absence of third person singular and past tense verbal endings (Baratz \& Baratz, 1969, p. 5). The absence of possessives in usage was the hardest part of Black English for me to grasp. "She ghetto, an he off da hook" were phrases that made me want to shut my door and lock it forever. "He my baby daddy" and "'she my gurl"' drove me crazy, creating fear that the students wrote the way that they spoke. ${ }^{5}$ Black dialect has the "concepts of plurality and possession, but they are not indicated by the addition of $-\mathrm{s}$ or apostrophes with $-\mathrm{s}$ " (Smitherman, 1998, p. 337).

Redundancy with subjects was another variation that I had to adjust to with "'My gurl, she got it," and "'my boy, he got a gurl." This use of "the double subject is another form used in Black English for emphasis" (p. 337). I had "had it" by the time I grasped that students omitted "have" in their speech. I found myself reduced to chewing rolls of anti-acids to calm the raw pit of my stomach, realizing that "when Black English speakers use been, White English speakers use have, has, or had plus been ... and that Black English uses only the verb form of been, regardless of the form of the subject" (p. 333). Students would make the following statements: "I been eatin" candy," and "'I been readin' yo assignment." But after noticing that my students would delete the third person singular present and past tense verb endings, I laughed to myself and realized that I could not change a dialect to be grammatically correct. I tried to focus what energy that I had left toward making sure that my students wrote correctly.

\section{CONCLUSION}

Language and culture are indeed intertwined, spun together like a spider weaves a web. Every web is unique and made specifically for a certain environment just like dialects within language define a specific culture. I began to learn from my students and understand their culture and dialect which remained stable due to certain conditions. One major contributing factor was residential insulation. Driving through certain areas of the county provided enough proof to where some of my students lived - the projects (government housing) and the apartment complexes. Within these communities, the Black English thrives, being completely shut off from Standard English. Secondly, a majority of my students were educationally deprived based on economic restraint and insulation. Certain jobs were suited for certain people - the better jobs with higher salaries required people with proper speaking skills, writing skills, and an education. The only exposure to Standard English that many received was at school; however, a majority of their influences stemmed from home. Lastly, the lack of motivation to learn is another factor that contributes to the stability of Black English. Certain issues within a family remained intact due to past generations. Many students were raised by grandparents - the older generation still encompassing a Black English from their times and still refusing to assimilate to modern standards.

Whatever the conditions, my White English had the same effect on them, opening the sewn gap of isolation. I commented one day to Student D, "'You are being too big for your britches," and the rest of the students replied, "'Mis, you mean he ain't all dat."

\footnotetext{
${ }^{5}$ Popular expressions that reference a person's background, sexual orientation, and relationship to another.
} 


\section{AUTHOR INFORMATION}

Amelia Simmons has been an Instructor of English and Reading at East Georgia State College since 2011. During that time, she has served as co-advisor to the Student Professional Association of Georgia Educators (SPAGE) and to the Criminal Justice Club. Mrs. Simmons has been an educator for twelve years, instructing students on the secondary and post-secondary level. Her research interests include issues related to teaching through the use of instructional strategies, linguistic variations in the rural South, African American Literature and its role within the classroom, the survival of Greek Mythology in our youth, and the great symbolism embedded in American Literature classics. Amelia Simmons, Humanities Division, East Georgia State College, 131 College Circle, Swainsboro, Georgia 30401 USA. E-mail: ajsimmons@ega.edu

\section{REFERENCES}

1. Baratz, S., \& Baratz, J. (1969). Negro ghetto children and urban education: A cultural solution. Florida Reporter, 7, 1-16.

2. Bushman, J. H. (1988). Teaching the English language. Springfield, NY: Charles C. Thomas.

3. DeStefano, J. (1973). Language, society, and education: a profile of Black English. Worthington, NY. Charles A. Jones.

4. Fromkin, V., \& Rodman, R. (1998). In introduction to language. New York, NY: Holt, Rinehart, and Winston.

5. Labov, W. (1998). The study of nonstandard English. In M. Burke (Ed.), Language: Readings in language and culture (pp. 313-320). Boston, MA: Bedford/St. Martin's.

6. McCrum, R., William C., \& MacNeil, R. (1992). The story of the English language. New York, NY: Penguin Group.

7. Millward, C. M. (1996). A biography of the English language. New York, NY: Holt, Rinehart, and Winston.

8. Smitherman, G. (1998). It bees dat way sometime: Sounds and structure of present-day Black English. In M. Burke (Ed.), Language: Readings in language and culture (pp. 328-343). Boston, MA: Bedford/St. Martin's. 